\title{
Governance in Central Banks: A Comparative Study of the Domestic and Foreign Banks
}

\author{
Grace Henni Tampongangoy \\ Faculty of Law, Sam Ratulangi University, North Sulawesi, Indonesia
}

\begin{abstract}
In every developing country, the availability of capital for development as a whole is experiencing difficulties and to overcome it, one of the sources of funding for the state is through foreign investment. In 2017, there were 40 banks owned by foreign banks in Indonesia. The research was conducted using a normative-legal research method. The research site was conducted at Bank Indonesia as Central Bank. The results show that the institutional situation of the central bank in the public sector varies from country to country, depending on historical, social and cultural factors. The presence of foreign banks in Indonesia cannot be separated from the State's goals which have been philosophically affirmed in the Preamble of the 1945 Constitution, to protect the Indonesian nation, promote public welfare, educate the nation's life and participate in world order. However, as it turns out into practice, the reality of the regulation of foreign banks in Indonesia has not shown a tendency to realize the State's goals because bank regulation is still very minimal and vulnerable to injustice to the state and injustice to the people of Indonesia.
\end{abstract}

Keywords: Bank; Comparative; Domestic Banks; Foreign Banks

DOI: $10.7176 / \mathrm{JLPG} / 87-13$

Publication date:July $31^{\text {st }} 2019$

\section{Introduction}

Banking is one of the most sensitive businesses all over the world and they are playing very important role in the economy of a country and Indonesia is no exemption. They do influence and facilitate to integrate the economic activities like resources mobilization, poverty elimination, production, and distribution of public finance. ${ }^{1}$ Janek, ${ }^{2}$ has analyzed the short-term effects of Foreign Banks entry on bank performance. He found that foreign banks entry affects negatively domestic banks' revenues from interest-earning assets, non-interest income, and profitability. Foreign banks entry can also raise the overhead costs of the local banks in short term. Foreign banks entry is likely to increase competition in the host country and foreign banks entry is associated with lower before tax profits, non-interest income, average loan interest rate and loan loss provisions. He also found, limited evidence that foreign entry increases a bank's overhead costs in the short run.

In this context, one of the business sectors that is allowed to invest in Indonesia, both domestic- and foreign investment is the banking business. Bank is a financial institution that have an important role in the economy of a country. The main function of the bank is to collect and channel funds to the public or it can be said that the bank is an intermediary institution that bridges the party with excess funds which is then channeled to those who lack funds. In this case banks play a very dominant role in contributing to Indonesian national development.

Foreign investment is one of the means to create economic relations that cannot be denied to a country, including Indonesia because it is expected to meet the needs of the state, company, and society. ${ }^{3}$ The relationship occurs because each party needs each other in meeting their needs and interests. On the one hand, recipient countries need funds, technology, and expertise or skills for the interests of development while on the other hand investors invest capital in the benefits of raw materials, labor, facilities and infrastructure, markets, guarantees of security and legal certainty in order to earn profits or profit.

The capital needed for the implementation of development can be provided by the government and by the community, especially the private sector. An ideal situation is that capital needs can be fully met by the ability of capital in their own country. But the reality presents that in general, in every developing country, the availability of capital for development as a whole is experiencing difficulties and to overcome it, one of the sources of funding for the state is through foreign investment. ${ }^{4}$ Foreign investment can provide benefits both directly and indirectly. Directly, foreign investment will provide additional funding for development and indirectly it can increase productivity and economic growth because through business processes, systems, management practices and new technologies, as well as a media link to export markets and supply chains internationally.

\footnotetext{
${ }^{1}$ Azam, Siddiqui, (2012). "Domestic and Foreign Banks' Profitability: Differences and Their Determinants," International Journal of Economics and Financial Issues Vol. 2, No. 1, pp.33-40

${ }^{2}$ Janek, U. (2004), Effect of foreign banks entry on bank performance in the CEE Countries. Tartu University Press, ISBN 9985-04-0416-5, order No.569.

${ }^{3}$ Rugebregt, R.V., Saleng, A., and Patittingi, F. (2016). "Government Policy in the Natural Resource Management of Local Community," Hasanuddin Law Review 1 (1), 122-129

${ }^{4}$ Ilmar, A. (2004). Hukum Penanaman Modal di Indonesia. Jakarta: Prenada Media. p. 102
} 
Foreign investment is one source of funds for development but for foreign investment, the Investment Laws provides certain restrictions as an effort to control foreign investment activities. Article 12 paragraph (1) of the Investment Law affirms that basically all sectors or types of businesses are open to investment activities except for sectors or types of businesses that are declared closed and open with certain conditions.

The determination of the type of business that is restricted then regulated in a Presidential Regulation No. 76 of 2007 concerning criteria and requirements for the preparation of closed and open business sectors with requirements in investment sector. Presidential Regulation No. 77 of 2007 concerning a list of closed and open business sectors with requirements in investment sector which are then replaced with Presidential Regulation No. 36 of 2010 concerning a list of closed and open business sectors with requirements in investment. Provisions regarding restrictions on the business sector apply both to domestic investment and foreign investment.

The Presidential Regulation No. 77 of 2007 regulates that the banking sector is an open sector. In Presidential Regulation No. 29 of 1999 that the maximum limit of foreign capital ownership in this banking sector is a maximum of $99 \% .{ }^{1}$ The establishment of a mixed bank is a foreign investment as referred to in the Investment Law which is direct investment. Foreign participation in banking in Indonesia is not only in the form of foreign ownership in Indonesian banks but it can also be through the establishment of a foreign bank in the status of a branch office or even a representative office with a head office in the country of origin. ${ }^{2}$

The description above shows that foreign investment is needed for the achievement of the goals and priorities of economic development policies. ${ }^{3}$ Thus, simultaneously implemented by preventing the occurrence of dominance and the negative impact of foreign investment in the national economy or it can be said that basically the investment laws provide guidance and certainty for investors, including foreign investors. In the same way, also maintain and protect the interests of the people of Indonesia and the national interests of the Republic of Indonesia.

\section{Domestic and Foreign Banks in the Indonesian Banking System}

Until 2017, there were 40 banks owned by foreign banks in Indonesia. The description above shows that basically the presence of foreign in the banking system in Indonesia can be seen in 3 (three) forms, namely the establishment of a branch or representative office, the establishment of a new bank, and the purchase of shares in an existing bank. The existence of foreign banks in Indonesia is developing related to business and investment needs, where Indonesia is very need foreign capital but the presence of foreign banks in Indonesia from a legal perspective continues to experience problems, such as:

The first; there is no clarity regarding the term of foreign banks. The banking law does not use the term of foreign bank but uses the term of bank that is domiciled abroad but in documents issued by Bank Indonesia, the term of foreign bank is often used for foreign bank branch offices in Indonesia while private banks are incorporated under Indonesian law, although the majority of its shares are controlled by foreigners it is not considered a foreign bank. Banking regulations in Indonesia do not clearly regulate this matter so that currently banks are Indonesian legal entities even though foreign majority ownership is still considered a non-foreign bank and subject to the Banking Laws while foreign bank branches or representatives are not regulated in the Banking Laws but in the Investment Laws.

The second; Bank Indonesia's policies and regulations for foreign banks and mixed banks are equal. All applicable provisions, including prudential are applied uniformly for all banks operating in Indonesia, both domestic banks, mixed banks and foreign banks. Foreign banks can do the same business with national banks, including in micro business and people's businesses and consumptive lending with very easy conditions that cause changes in the behavior of people to be more consumptive.

The third; Act No. 10 of 1998 does not have legal substance that can solve juridical problems related to the legal form of foreign banks. Foreign banks remain legal entities following their head office abroad and are an important part of the organization of its head office. As a consequence, all financial policies of foreign banks are very dependent on their head office, and in general foreign banks make loans to large companies because they get large financing from their head office. ${ }^{4}$ This will have an impact, the big businessmen who will prefer to conduct transactions with foreign banks because they have the opportunity to obtain more funds. As a result, domestic banks will lose potential customers.

The fourth; multiple licenses for the operation of foreign banks business in Indonesia have not been explicitly regulated. In other countries the practice license to banking operations for foreign banks is given in

\footnotetext{
${ }^{1}$ Article 3 PP No. 29 of 1999 regarding the Purchase of Commercial Bank Shares: the total share ownership of the Bank by Foreign Citizens and or Foreign Legal Entities obtained through direct purchases or through a maximum number of exchanges is $99 \%$ (ninety-nine per hundred) of the total shares of the Bank concerned.

${ }^{2}$ Supriyanto, E.B. (2018). Menyoal Kepemilikan Bank. KOMPAS, Tuesday, 21 June 2018.

${ }^{3}$ Irwansyah., Hakim. W., and Yunus, A. (2017). "Environmental Audit as Instrument for Environmental Protection and Management". The Business and Management Review, 9(2), 228-232

${ }^{4}$ Mulaiman, D.H., Wimbo, S., (2003). Fungsi Intermediasi Bank Asing dalam Mendorong Pemulihan Sektoril di Indonesia. The Journal of Directorate of Research and Banking Arrangement. Paper Report in 2003.
} 
multiple, so that after the bank business has been running for three up to four years, then licenses are given to receive deposits or third-party funds with a certain amount.

The fifth; supervision and coordination between "host country" and "home country" is unclear even though this is important to regulate given that many transactions and irregularities even crimes that can occur in transnational transactions. There is no clarity regarding the disclosure of information from the host country to the home country related to the examination of foreign banks domiciled in Indonesia. At present there is a "home and host country supervision" but it is not running optimally because certain formalities are needed, for example, it preceded by agreements between banking regulators in various countries. Serious problems related to the presence of foreign banks as multinational corporations either in the form of holding companies and joint ventures as a result of investment openness in Act No. 25 of 2007 in Indonesia. The emergence of Multinational Corporation Crime such as crimes in the sector of investment, and money laundering.

The sixth; lawyers and legal consultants of foreign bank are closed. The principle of reciprocity with other countries has not been regulated in the Banking Laws. When in a legal case, Indonesian banks open their customer data, the same thing should be done by foreign banks to open customer data for law enforcement needs in Indonesia.

The seventh; the limitations of Bank Indonesia in conducting capacity assessments and compliance monitoring of foreign banks because the host country is fully responsible for their banks in Indonesia so that irregularities and crimes are very easy to occur and their home countries can easily protect individuals from foreign banks, especially if there is no extradition agreement between Indonesia and the country of origin of the foreign bank. So here is a difference and a comparison of banking arrangements between Southeast Asian countries (Table 1).

Table 1. Comparison of Banking Arrangements between Southeast Asian Countries

\begin{tabular}{lccccc}
\hline \multicolumn{1}{c}{ Country } & License & $\begin{array}{c}\text { Min. Capital } \\
\text { (USD mil) }\end{array}$ & $\begin{array}{c}\text { Foreign Equity } \\
\text { Participation }\end{array}$ & $\begin{array}{c}\text { Hosting bank from } \\
\text { ASEAN }\end{array}$ & Restriction \\
\hline Indonesia & Single & 334 & $99 \%$ & 7 banks & No \\
Singapore & Multiple & 1.200 & $10 \%$ & 9 banks & Branch, ATM \\
Malaysia & Multiple & 600 & $30 \%$ & 6 banks & Branch, ATM \\
Thailand & Multiple & 325 & $40 \%$ & 6 banks & Branch, ATM \\
Philippines & Multiple & 150 & $49 \%$ & 4 banks & Branch, ATM \\
\hline
\end{tabular}

Source: Primary data, edited 2019.

On this basis, Indonesia in the life of the nation has a legal politics that will be different from other nations. the national legal policy is the basis of policy in the field of law, both the will and the prevailing ones, which are derived from the values that live in the community (living law) to achieve the goals of the aspired state. The objectives of the national legal policy include two interrelated aspects, namely: a) As a tool that can be used by the government to create a desired national judicial system; and b) With the national legal system, the grander aspirations of the Indonesian people will be realized. In the life of the nation and state supported by the economic sector, it is necessary for development in the economic field. In the process of economic development banking activities is an essential element.

Banking financial institutions have an essential role in driving the economy of a country. This is due to the presence of banks, one of which is useful for collecting funds directly from the community and channeling it back to the community through credit law institutions. In addition, banking institutions as the main source of financing are obliged to facilitate the development of the market economy.

By looking at these conditions, the potential for legal conflicts arises. Cross-country bankruptcy is a complicated problem and requires regulation. An example of a case that could be a concern related to foreign banks was the bankruptcy case of PT. Meranti, in which one of the creditors who filed for bankruptcy was Maybank. In this case, all creditors who filed for bankruptcy were willing to solve peacefully but Maybank rejected even though in a process of bankruptcy against debtors, peace was the most prioritized effort. As a result of the bankruptcy, Maybank as one of the creditors controls the assets of PT. Meranti, in this case is a Stateowned enterprise, so that this becomes the object of examination in the attorney regarding corruption.

The refusal of Maybank to peace then led to allegations from Maybank to take over State assets and even raised allegations of a fictitious credit agreement between PT. Meranti and Maybank as a conspiracy to take over assets by using the bankruptcy line. This is one of the conditions that causes a situation to arise that does not provide protection for the interests of the State.

The presence of foreign banks is very important because Indonesia needs foreign capital in driving development and economic growth. Foreign banks are very important in moving foreign exchange and stabilizing the rupiah exchange rate but the presence of foreign banks in Indonesia is still vulnerable to the emergence of problems, especially in relation to the position of banks as an intermediary institution in national 
economic growth. ${ }^{1}$

Foreign banks are very easy to established and obtain facilities, while Indonesian banks are very difficult to be established in other countries. Likewise, in investment in the form of shares, Indonesian rules provide a maximum limit of 99 percent of foreign ownership while in other countries, the maximum limit of foreign ownership is only 45 percent, such as in Singapore and Malaysia.

Current Branch Offices of Foreign Banks in Indonesia are following the legal entity of their home country so that supervision is carried out by the Investment Coordinating Board, but if the investment is carried out in the form of a subsidiary where the subsidiary has an Indonesian legal entity, supervision is carried out by the Financial Services Authority. The supervision of the Financial Services Authority on foreign banks can be carried out if the existence of the bank is not in the context of investment and if the licensing is by the Investment Coordinating Board, all oversight is within the authority of the Investment Coordinating Board.

The institutional situation of the central bank in the public sector varies from country to country, depending on historical, social and cultural factors. In more developed countries, the independence of the central bank is common; but even in some developing countries, the central bank is also formally independent. ${ }^{2}$ Hence, the granting of independence to the central bank varies from country to country and depends on the maturity level reached by democracies. Countries that are more mature usually grant independence to their central banks, with the counterpart of greater accountability.

\section{Conclusion}

The presence of foreign banks in Indonesia cannot be separated from the State's goals which have been philosophically affirmed in the Preamble of the 1945 Constitution, to protect the Indonesian nation, promote public welfare, educate the nation's life and participate in world order. However, as it turns out into practice, the reality of the regulation of foreign banks in Indonesia has not shown a tendency to realize the State's goals because bank regulation is still very minimal and vulnerable to injustice to the state and injustice to the people of Indonesia.

These conditions arise the phenomenon of inequality between foreign banks and national banks due to unclear arrangements regarding the status, position and requirements of foreign banks in the banking system in Indonesia so that researchers were interested in conducting research to find a clear status and position of foreign banks in the banking system in Indonesia in terms of the position of foreign banks in the banking system and the position of foreign banks associated with investment law. The both aspects are expected to be able to create harmony between public and private interests in a foreign investment in the banking sector.

\section{References}

Atmasasmita, R. (2010). Globalisasi Kejahatan Bisnis. $2^{\text {nd }}$ edition. Jakarta: Prenada Media. p.53

Azam, S, (2012). "Domestic and Foreign Banks' Profitability: Differences and Their Determinants," International Journal of Economics and Financial Issues Vol. 2, No. 1, pp.33-40

Faria, F. D. A., \& Streit, R. E. (2016). Governance in central banks: a comparative study of the governance practices used by the central banks of Brazil, Canada and England. Revista de Administração Pública, 50(5), 765-794.

Ilmar, A. (2004). Hukum Penanaman Modal di Indonesia. Prenada Media: Jakarta.

Irwansyah., Hakim. W., and Yunus, A. (2017).“Environmental Audit as Instrument for Environmental Protection and Management". The Business and Management Review, 9(2), 228-232

Janek, U. (2004), Effect of foreign banks entry on bank performance in the CEE Countries. Tartu University Press, ISBN 9985-04-0416-5, order No.569.

Mulaiman, D.H., Wimbo, S., (2003). Fungsi Intermediasi Bank Asing dalam Mendorong Pemulihan Sektoril di Indonesia. The Journal of Directorate of Research and Banking Arrangement. Paper Report in 2003.

Rugebregt, R.V., Saleng, A., and Patittingi, F. (2016). "Government Policy in the Natural Resource Management of Local Community," Hasanuddin Law Review 2 (1), 122-129

Supriyanto, E.B. (2018). Menyoal Kepemilikan Bank. KOMPAS, Tuesday, 21 June 2018.

Waxman, M. (1998). A legal framework for systemic bank restructuring. Available at SSRN 172984 or http://dx.doi.org/10.2139/ssrn.172984

\footnotetext{
${ }^{1}$ Atmasasmita, R. (2010). Globalisasi Kejahatan Bisnis. $2^{\text {nd }}$ edition. Jakarta: Prenada Media. p.53

${ }^{2}$ Faria, F. D. A., \& Streit, R. E. (2016). Governance in central banks: a comparative study of the governance practices used by the central banks of Brazil, Canada and England. Revista de Administração Pública, 50(5), 765-794.
} 